\title{
Governance Improvement in India and China Based on the View of Social and Economic Development
}

\author{
Qifa Jiang \\ International Business School \\ Yunnan University of Finance and Economics \\ Kunming, China \\ fagenjiang3@163.com
}

\begin{abstract}
Governance as a kind of institution, can play a critical role in economic development. Being emerging economies, India and China must reform and improve governance to fit in with the rapid change of economic and social facts. After conceptualization of governance, the author constructs an assessment framework based on the decomposition of social, and economic arenas - altogether 7 indicators, 5 and 2 for social, and economic area respectively, to measure governance improvement in India and China by using the selected indicators sequentially. Though confronting many difficulties, the two countries have made great progress of governance in recent years. The governance improvement in the two countries can give many enlightenments for other developing countries. Certainly, it is critical to find a desired approach of governing to push a nation's development and improve governance continuously with the social and economic changes over time.
\end{abstract}

Keywords: governance, improvement, economic growth, social development

\section{INTRODUCTION}

As being emerging economies, India and China share high similarity in many aspects. Owned vast territory, with colorful cultures and diverse ethnicities, both ancient civilized countries changed the political system and rebuilt their countries in the middle of 20th century.

After a long time of center-planned socialist economy, China started its 'Reforming \& Opening-up' in 1978, and India initiated its 'Economic Liberalization' in 1991. The policies opened the two countries to a global and competitive market, and greatly stirred up the economic growth. In recent years, the two countries develop rapidly; their GDP growth rates are more than 6\% per year from 2010 (Data source: https://data.worldbank.org/).

However, the two nations are confronting many challenges behind the great achievement, such as poverty reduction, underdeveloped infrastructure, environment protection, antiterrorism, economic reform and growth, etc. All these problems are huge threats to the government in such a billionlevel-population country. Thus, it is a great wisdom for the elite to think how to steer the giants: how to keep political stability, deal with inequality, make social progress, develop economy, and finally find an opportunity to catch up the developed countries. In this process, the essential prerequisite is to have a GOOD government, which can play a critical role for the development [1].

Bing a paradigm shift, the study of 'good government' now mainly changes into the government's role, structure and operation process, or the way social problems are resolved [2], which appears a more plausible and ambiguous notion, 'governance'.

Governance, generally regarded as a kind of formal institutions, will shape the direction of economic change as well as evolve incrementally with economy with other relevant institutions. Then there is a strong case to be made for improving government (and other institutions) as a key strategy for pursuing economic performance [3]. Thus, Indian and Chinese economic development will show how governance accounts for their economies, and hence largely reflect the evolution of their governance.

The practice of governance in the two most populous nations can supply valuable lessons to other developing countries. In the next decades, the rise of China, and having a strong chance, India, will reshape the power of the world greatly. It is one key area of hot studies to track down their success, and explain the roles of the two countries' governments and the styles of governance in the process of development, as well the trajectory - evolution or improvement - of governance.

Therefore, after a theoretical and framework analysis of governance, this paper will mainly discuss the following questions:

1. What is the major progress of governance for the two countries in the process of economic and social development?

2. How can the two countries' governance improve incrementally and be fit with the change of social and economic facts?

3. Which country has stepped forward more in terms of governance improvement?

\section{CONCEPTUALIZATION AND STRATIFICATION}

A. Governance as an Interdisciplinary Perspective

Being a very old concept, the studies and debates of governance in European can be traced back to the Trilateral 
Commission and was triggered by the problematization of traditional forms of government in the beginning of the 1990s [4]. Now the term 'governance' has already been used in various contexts [5]. The popularity of governance reflects the fact that it can be applied to a wide range of issues, relationships and institutions involved in the process of managing public and private affairs, as well it shows the complexity of how to conceptualize the term. Various disciplines emphasize different modes of governance from business, public management, politics, economics, and sociology [6]. This research mainly focuses on statehood level, sometimes called as 'government governance'.

More generally, governance can be considered as a mechanism for resolving common public problems [7], or a government's ability to make and enforce rules, and to deliver services, regardless of whether that government is democratic or not [8]. A more comprehensive definition by the United Nations Development Programme (1997), is "the exercise of economic, political and administrative authority to manage a country's affairs at all levels. It comprises the mechanisms, processes and institutions through which citizens and groups articulate their interests, exercise their legal rights, meet their obligations and mediate their differences" [9]

The study of governance also evolves with the investigation of public management and politics. In modern society, after the transition from government to governance [10], efficient, democratic, responsive, and transparent government is the ultimate goal of all kinds of administration [11]. A new philosophy of good governance has emerged simultaneously with a new paradigm of New Public Administration, or New Governance $[12 ; 13 ; 14]$, which all entail some basic principles such as sound public sector management (efficiency, effectiveness and economy), societal accountability (engagement, public participation, coordination, ethical value, integrity), exchange and free flow of information (transparency), and a legal framework for development (justice, rule of law, respect for human rights and liberties, sustainability).

\section{B. The Focused Topic and Stratification}

Before focusing on our discussed topic, we have to better measure good governance, and then we can observe the time series data, find the changes of indicators over time. Afterwards we are able to come to conclusion whether governance of a country improves or not.

Good governance is at the cutting edge of public administration. According to UNESCAP (2009), good governance has 8 major characteristics: Participation, Rule of law, Transparency, Responsiveness, Consensus Oriented, Equity and Inclusiveness, Effectiveness and Efficiency, Accountability. Good governance assures that "corruption is minimized, the views of minorities are taken into account and that the voices of the most vulnerable in society are heard in decision-making. It is also responsive to the present and future needs of society" [15]. This is a very high standard for developing countries. Therefore, it is reasonable for us to change our method for governance measurement in developing countries; we can test the change of governance - its improvement, to examine the progress of governance over time. Meanwhile, this method is conformable to the philosophy of public administration, in which processes and management should be continuously improved [16].

Other pundits also discuss how to testify governance. Governance will touch on all aspects of political power. Therefore, it is an awesome task to estimate governance because of conceptual problem and disagreement on the composition of quality government. Fukuyama (2013) suggests four approaches: (1) procedural measures, such as the Weberian criteria of bureaucratic modernity; (2) capacity measures, which include both resources and degree of professionalization; (3) output measures; and (4) measures of bureaucratic autonomy. Yet the indicators are still highly conceptual and dissenting [8]. Hyden and Court (2002) disaggregated governance into six functional dimensions and institutional arenas, e.g. civil society, political society, government, bureaucracy, economic society, judicial system, as well as suggested indicators used in governance assessment [17].

Because of the difficulty of measuring governance, one approach is to break governance into its constituent parts, in other words, the making and enforcing of rules. To simplify the question, many papers just focus on the ability of a political system to enforce rules and to deliver services, i.e., state capacity, which is defined as the ability of the state to dominate the individuals of a given territory and operationalized as tax compliance [18]. This simplification can be easily understandable, as government and statehood are prerequisites for good governance; If a nation is insufficient of state capacity or democracy, its governance will be poor [19].

In this paper, we would examine the governance improvement of India and China. Yet the existing literature tells us it is a severe job owing to the decomposition of governance. Thus, we would disaggregate governance in a simple and traditional way - as Levy \& Fukuyama (2010) proposed - into 3 broad dimensions of development, i.e. economic, social \& cultural, and political arenas [20].

Comparing other measuring methods, we would like to levy more on performance or output indicators, such as GDP per capita, GDP growth rate, Happiness Index, etc. which reflects a results-oriented philosophy. Due to its controversial nature of political arenas, we would just focus on economic and social arenas when discussing governance improvement in India and China.

\section{COMPARISONS OF GOVERNANCE IMPROVEMENT}

As Fukuyama (2013) pointed out, one reason of the inadequate existing quantitative measures of governance is that some nations, like China or the United States, also India, are so large, complex, and thus difficult to simplify the model [8]. Therefore, we would discuss each indicator according to Table 1 , and then compare the improvement of the two countries which will be based on the time-series data. The best approach might be to construct a composite indicator, yet it is hard to accomplish the task by common consent at present.

\section{A. Abbreviations and Acronyms Social and Cultural Arena}


Most indicators in this arena are relevant to some parts of the Human Development Index (HDI), which is released by United Nations Development Programme and included in a Human Development Report each year. The two countries show distinctions in this area; in recent 20 years HDI of the two countries grows very fast, as Table 2 shows, their annual growth rates rank top countries. Basically, China makes huge progress for each index, and changes the scores largely, hence improves governance greatly. India also improves greatly but has less progress in this area; and even some indicators, for example, Happiness Index, falls in recent years.

TABLE I. THE CITED INDEXES

\begin{tabular}{|c|c|c|c|c|}
\hline Areas & Dimensions & Main Indicators & Meaning \& Explanation & Sources \\
\hline \multirow{5}{*}{ Social } & $\begin{array}{c}\text { Living } \\
\text { standard }\end{array}$ & Life Expectation & Health outcomes & $\begin{array}{l}\text { United Nations Development Programme's Human } \\
\text { Development Report (http://hdr.undp.org/) }\end{array}$ \\
\hline & $\begin{array}{l}\text { Education } \\
\text { rights }\end{array}$ & Literacy rate & Education achievements & $\begin{array}{l}\text { United Nations Development Programme's Human } \\
\text { Development Report (http://hdr.undp.org/) }\end{array}$ \\
\hline & Anti-poverty & Poverty Ration & $\begin{array}{l}\text { Poverty headcount ration (\% of } \\
\text { population) }\end{array}$ & The World Bank Databank (https://data.worldbank.org/) \\
\hline & $\begin{array}{l}\text { Gender } \\
\text { equality }\end{array}$ & $\begin{array}{l}\text { Gender Inequality } \\
\text { Index } \\
\end{array}$ & $\begin{array}{l}\text { A composite measure of gender } \\
\text { inequality }\end{array}$ & $\begin{array}{l}\text { United Nations Development Programme's Human } \\
\text { Development Report (http://hdr.undp.org/) }\end{array}$ \\
\hline & Happiness & $\begin{array}{l}\text { World Happiness } \\
\text { Index } \\
\end{array}$ & $\begin{array}{c}\text { A landmark survey of the state } \\
\text { of global happiness }\end{array}$ & World Happiness Report (http://worldhappiness.report/) \\
\hline \multirow{2}{*}{ Economic } & $\begin{array}{l}\text { Individual } \\
\text { income }\end{array}$ & PPP per capita & 2010 constant PPP per capita & The World Bank Databank (https://data.worldbank.org/) \\
\hline & GDP growth & Annual growth rate & Real growth rate $(\%)$ & The World Bank Databank (https://data.worldbank.org/) \\
\hline
\end{tabular}

TABLE II. THE $1950 \& 2015$ HDI AND ITS GROWTH RATE

\begin{tabular}{|c|c|c|c|c|c|}
\hline Country & 1950 Score & 2015 Score & 2015 Rank & Category & 1995-2015 Average Annual HDI Growth (\%) \\
\hline India & 0.160 & 0.624 & 131 & Medium Human Development & 1.52 \\
\hline China & 0.163 & 0.738 & 90 & High Human Development & 1.57 \\
\hline
\end{tabular}

a. Source: United Nations Development Programme's Human Development Report (http://hdr.undp.org/) [21]; 1950 scores from Crafts (1996) [22].

\section{1) Life Expectation and Literacy Rate}

For the two countries, these are two remarkable achievements of national development as well as governance, shown in Figure 1 and Figure 2. Life expectation and literacy rate roar substantially, particularly for China, which shows its greater potential of next step development.

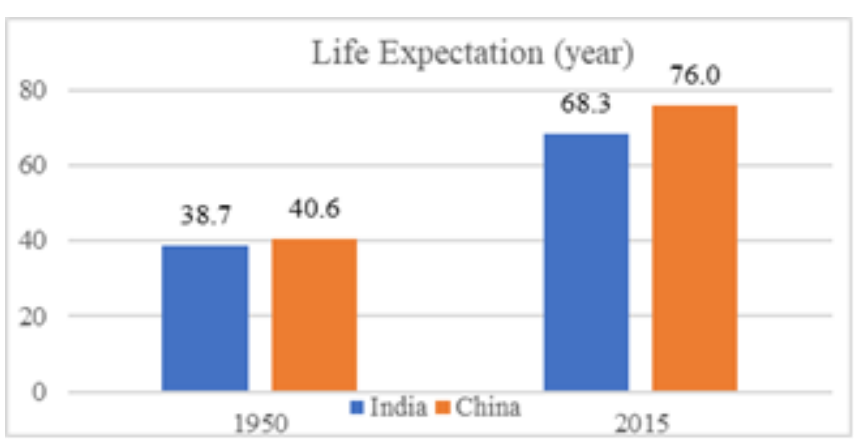

Fig. 1. Life Expectation Change

b. Source: United Nations Development Programme's Human Development Report (http://hdr.undp.org/) [21]; 1950 scores from Crafts (1996) [22].

\section{2) Anti-poverty Performance}

There are many methods to measure poverty. Here I will just simply count extreme poverty headcount ratio. It means the percent of population living under $\$ 1.90$ a day, at 2011 dollars (purchasing power parity). This method is widely used by the World Bank, United Nations, etc.

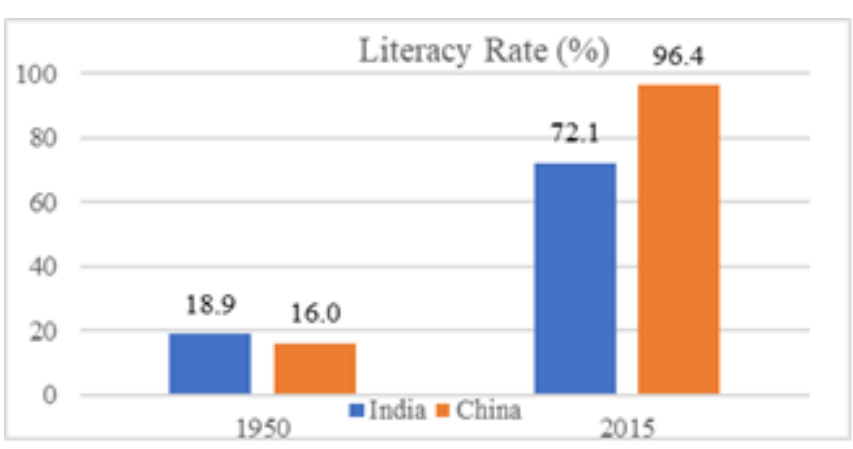

Fig. 2. Literacy Rate Change

c. Source: United Nations Development Programme's Human Development Report (http://hdr.undp.org/) [21]; 1950 scores from Crafts (1996) [22]

China is well known for its efforts to reduce poverty [23]. Even in 1990s, poverty in China is more severe than India. However, China now almost wipes out urban poverty and gets the final step to eradicate rural poverty [24]. It is executing a national strategy of Accurately Poverty Alleviation Program, which ambitiously targets the goal of efforts to eliminate extreme poverty by the end of 2020 in China [25]. Decades of economic growth helps China fulfill its goal.

India has also achieved significantly; it cuts absolute poverty levels by more than half in about 20 years. One of the 
main reasons for record decline in poverty is India's rapid economic growth rate since 1991.

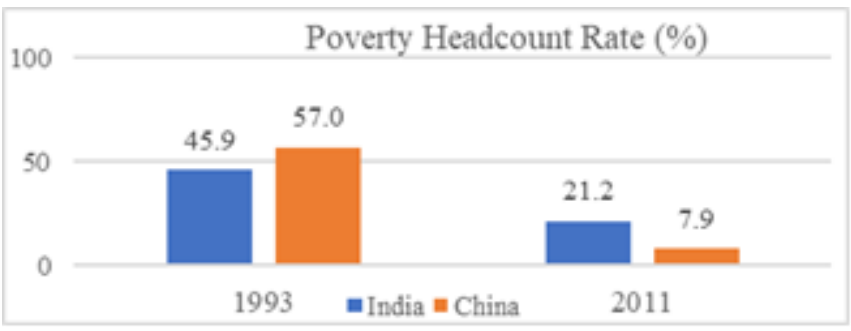

Fig. 3. The Change of Poverty Rate

d. Source: The World Bank Databank (https://data.worldbank.org/).

\section{3) Gender Equality}

In terms of gender equality, the two countries show great difference. China has a good reputation for women's right protection, in 2015 its Gender Inequality Index ranks 37, even ahead of United States (ranking ahead means a better gender equality).

On the other hand, India should promote its women's rights more quickly; its Gender Inequality Index still higher than 0.50 , which ranks 125 and lags behind most countries. Using the Template

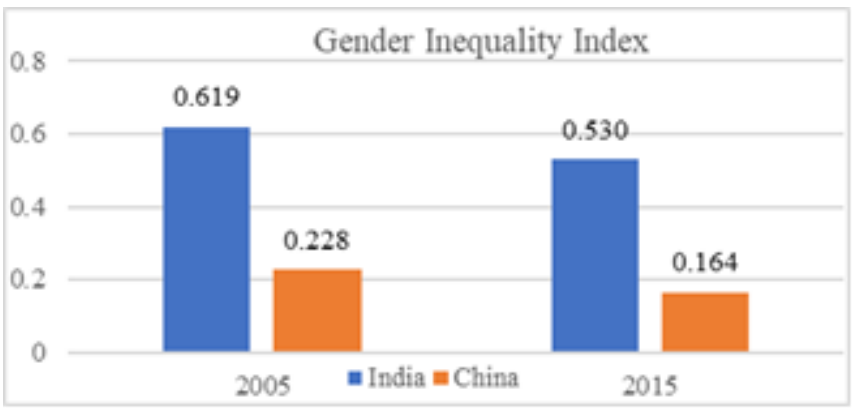

Fig. 4. Changes of Gender Inequality Index

Source: United Nations Development Programme's Human Development Report (http://hdr.undp.org/). The highest score is 1.0; whereas the higher score, the more (http://hdr.undp.org)

\section{4) State Happiness}

Generally speaking, the two countries share a medium score for Happiness Index which is annually issued from 2008, yet India's score reduces in recent years, which indicates that a worse change exists in India. On the contrary, Chinese data is positively relevant with its high economic growth, and now its score is more than India's.

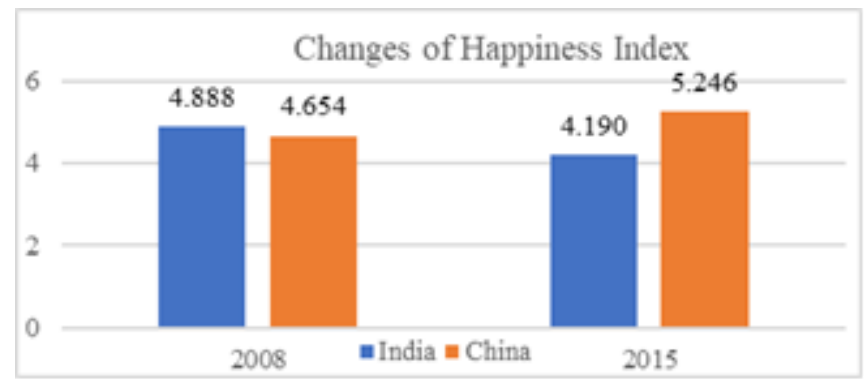

Fig. 5. Changes of Happiness Index

f. Source: World Happiness Report (http://worldhappiness.report/). The highest score is 10; whereas the higher score, the better situation.

B. Authors and Affiliations Economic Arena

The two countries have very good performance in this arena. From 1960, the annual growth rate is much higher than the average of the world. In recent years the growth rate speeds up. Yet because of starting from a low base, GDP per capita of the two countries still does not exceed the world average level.

\section{1) Changes of GDP Per Capita}

From 1990s GDP per capita grows very fast in the two countries. Especially for China, though it started at the approximate similar conditions as India, now GDP per capita is almost 5 times of its counterpart. In 1960, GDP per capita of India, China and the world average is 304.23, 191.79, and 3682.99 at constant 2010 US\$ respectively; only after its reforming and opening, China exceeded India in 1984, in which year it is $434.37,481.36$, and 6499.78 respectively. In 2016 , it is $1861.49,6893.78$, and 10418.36 respectively. The trends are shown in Fig. 6.

\section{2) Annual GDP Growth Rate}

As shown in Fig. 7, in most years GDP growth rates of the two countries are much higher than average of the world, particularly for China. With the rapid growth of development, China becomes the second largest economy in the world. Except a few years, its annual growth rates are always larger than $5 \%$

In contrast with China, India's growth rate varies more greatly since 1961 . For some years its growth rates were even lower than 0 , though some years the rates might be higher than $10 \%$. The bigger change of India's growth rate depicts that to some extent its economy is much more vulnerable than China when encountering the global market. In a word, China has a better industrial base than India.

\section{DISCUSSIONS}

\section{A. General Commentary for Data Analysis}

At the start the stories were almost the same: India got its independence in 1947, and China was liberated in 1949; In 1950, HDI of the two nations shows very little difference.

However, over 70 years' development the two nations appear very large differences almost in all aspects. Although India is one of the world's fastest-growing large economies, it ranks 131 out of 188 countries on the UNDP's Human Development Index [21]. While several parts of the country have made tremendous progress on some socio-economic indicators, other regions are lagging behind, and significant disparities exist in the achievement of outcomes between and within states [26]. 


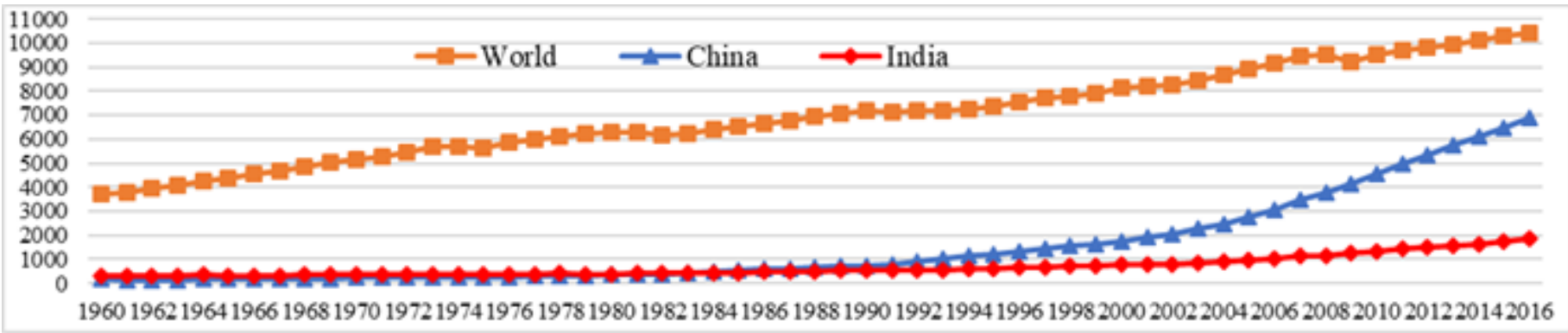

Fig. 6. Change of GDP per capita (constant 2010 US\$)

g. Source: The World Bank Databank (https://data.worldbank.org/)

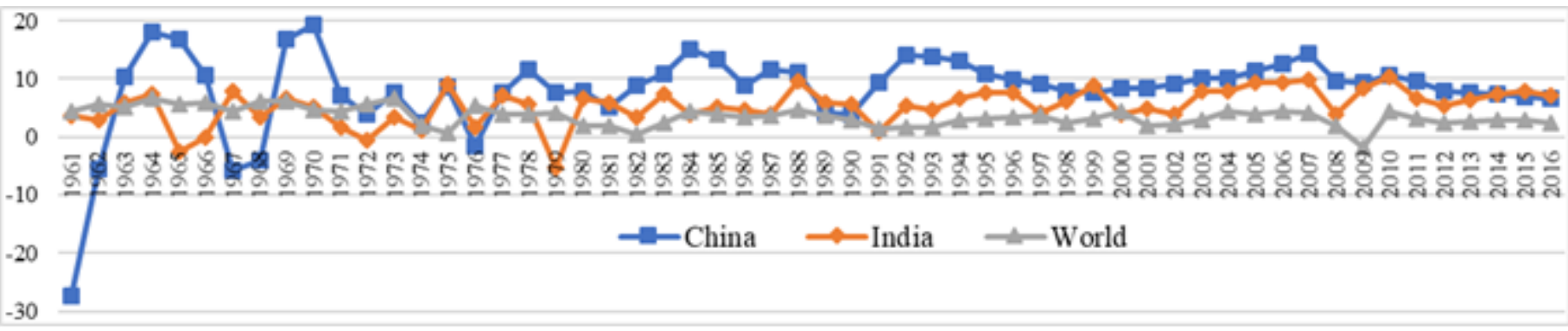

Fig. 7. GDP Annual Growth Rate

h. Source: The World Bank Databank (https://data.worldbank.org/)

On the other side, China' HDI is 0.738 in 2015, which ranks 90 and is categorized as the country of High Human Development. In 2016, GDP per capita in China is almost 4 times of India at constant 2010 US \$. China's rapid growth of development indicates that its governance is improving much more greatly than India [27].

\section{B. Causes of Differences in Development over Time}

Many factors can account for this big difference of development in the two nations; yet governance can certainly be one of main determinants. For example, in some case some scholars may attribute lagging behind in India to the facts that there exists poor efficiency of legislation and its slow implementation, and conflicts between religions [28]. However, all these factors can be integrated into one dimension of governance. By contrast, efficiency of public administration in China is well recognized by all people.

\section{The Sound Method for Governance Improvement}

Governance, as a kind of system to solve public problems [7], will integrate into the social-economic process, and enforce itself during the development. When changing the system, there will be highly risky because of huge switching cost [29]. Therefore, being a system, it will be locked-in to the decisionmakers in the nation, which results in path dependence. This truth explains why the elite in a nation who steer the economy should shift the system carefully: drastic transition always brings severe turbulence; the switching cost will accumulate so high that no nation can afford it. Thus, the best solution of governance improvement is to innovate the economy and governance moderately.

\section{CONCLUSIONS}

Governance owns some attributes like high confusion, broad application, high difficulty to conceptualization and operationalization, and few approaches to measure and assessment, etc. In this paper we try to construct an assessment system based on some popular principles and make some efforts to analyze governance improvement for two emerging economies, i.e. India and China and conclude some enlightenments for other developing countries.

On popular principles of governance, we choose some typical indicators to assess governance improvement of the two countries. According to our selected indicators of economic and social arenas, we analyze the evolution of each indicators in sequence. Thereafter, by comparative analysis and after a primary and conceptualized analysis, we can conclude that:

(1) Though confronting many huge difficulties, the two countries have made great progress of governance in recent years. The progress is down-to-earth with rapid economic and social development. Their successes are precious knowledge for many other developing countries which are still suffering from economic stagnation, domestic conflict, regional separation, and even terrorist attack, etc.

(2) In general China presents a better performance than India; it gets much higher scores for our most selected indicators. However, China must promote its state happiness and go further its economic and political reforming. On the other hand, India has an urgent push for its social and cultural situations.

(3) Governance can play a critical role in economic and social development. Moreover, it also will explain many development differences of many developing countries which started at a similar point, such as Indian and China. Different 
styles and abilities of governance will result in great distinctions of development after years of evolution.

(4) Governance, as a kind of institutions, will show a path dependence when selecting the fundamental political and legal system. Yet gradual improvement can remedy the initial path selecting cost. This is particularly expressed by the two incidents: Reforming and Opening-up in China in the late 1970s, and Economic Liberation in India in the early 1990s. The following decades witness the roaring growth of the two countries. Therefore, it is critical to improve governance continuously and find a desired approach of governing to push a nation's development.

\section{ACKNOWLEDGMENT}

This work is supported by National Natural Science Foundation of China (NSFC) under Grant 71463061 (Project Title: Study on Participatory Appraisal Mechanism for Local Government Public Works) and China Scholarship Council (CSC NO: 201608535060). The author expresses his great gratitude to NSFC and CSC for the sponsorship.

\section{REFERENCES}

[1] G. Hyden, J. Court and K. Mease, "Government and Governance in 16 Developing Countries," World Governance Survey Discussion Paper 6, London: The Overseas Development Institute (ODI), 2003.

[2] C. Heinrich and Jr. L. Lynn, (eds), Governance and Performance: New Perspectives. Washington D.C.: Georgetown University Press, 2000.

[3] D. North, Institutions, Institutional Change and Economic Performance. Cambridge: Cambridge University Press, 1990

[4] Eva Sørensen and Jacob Torfing, "The European Governance Debate," the 21st IPSA World Congress of Political Science, Santiago, Chile, July $12-16,2009$.

[5] Mathias. Koenig-Archibugi, "Global governance," In: Michie, Jonathan, (ed.) The Handbook of Globalisation. Edward Elgar Publishing Ltd, Cheltenham, 2011.

[6] R. Rhodes, Understanding Governance: Policy Networks, Governance, Reflexivity and Accountability. Bristrol, PA: Open University Press, 1997.

[7] Myungsuk Lee, "Conceptualizing the New Governance: A New Institution of Social Coordination," the Institutional Analysis and Development Mini-Conference, May 3rd and 5th, 2003, Workshop in Political Theory and Policy Analysis, Indiana University, Bloomington, Indiana, USA, 2003

[8] Francis. Fukuyama, "What is Governance?" Governance: An International Journal of Policy, Administration, and Institutions, Vol 26, No. 3, pp. 347-368, 2013.

[9] United Nations Development Programme, "Governance for sustainable human development,” UNDP policy document, New York, 1997.
[10] Maria. Bonnafous-Boucher, "From Government to Governance", Ethical Perspectives: Journal of the European Ethics Network, Vol. 12, No. 4, pp. 521-534, 2005.

[11] D. John, D. Kettle, B. Dyer \& W. Lovan, "What Will New Governance Mean for the Federal Government?" Public Administration Review, Vol. 54, No. 2, pp. 170-175, 1994.

[12] R. A. W. Rhodes, "The New Governance: Governing without Government", Politica1 Studies, Vol. XLIV, pp. 652-667, 1996.

[13] B. G. Peters \& J. Pierre, "Governance Without Government? Rethinking Public Administration", Journal of Public Administration Research and Theory: J-PART, Vol. 8, No. 2, 223-243, 1998.

[14] World Bank, Governance. Washington, D.C., 1993.

[15] UNESCAP, What is Good Governance? New York, 2009.

[16] International Organization for Standardization (ISO), ISO 9001:2015: Quality Management Systems - Requirements. Geneva: ISO Central Secretariat, 2015.

[17] G. Hyden \& J. Court, "Governance and Development," World Governance Survey Discussion Paper 1, Tokyo: United Nations University, 2002.

[18] Mattias Ottervik, "Conceptualizing and Measuring State Capacity: Testing the Validity of Tax Compliance as a Measure of State Capacity", Working Paper Series 2013:20, Gothenburg, Sweden: The Quality of Government Institute (QOG), 2013.

[19] Tanja A. Börzel, "Governance with/out Government. False Promises or Flawed Premises?" SFB-Governance Working Paper Series, No. 23, Berlin: Research Center (SFB) 700, 2010.

[20] Brian Levy \& Francis Fukuyama, "Development Strategies: Integrating Governance and Growth," Policy Research Working Paper 5196, Washington, D. C.: The World Bank, 2010.

[21] United Nations Development Programme (UNDP), Human Development Report. New York, 2016.

[22] N. F. R. Crafts, "The Human Development Index and changes in standards of living: Some historical comparisons", European Review of Economic History, Vol. 1, No. 3: 299-322, 1997.

[23] Minning, "The last, toughest mile: China's new approach to beating poverty", The Economist, Apr 29th, 2017.

[24] Elizabeth Stuart, "China has almost wiped out urban poverty. Now it must tackle inequality," Theguardian.com, 19 August 2015, Retrieved 28 December 2017.

[25] Xinhua, 01/05/c_136874603.htm, 2018.

http://www.xinhuanet.com/english/2018

[26] Urvashi Prasad, "India's economy is growing fast, but its poorest areas lag behind. Here's why this could be about to change", World Economic Forum, https://www.weforum.org/agenda/2018/06/transforming-india-humandevelopment-indicators-adp/, 2018.

[27] Jiang Qifa, "The relationship between economic development and governance improvement", Asian B\&R Conference on International Business Cooperation: The Third International Symposium, Kunming, China, October 19-20, 2018.

[28] Barbara D. Metcalf, "Imrana: Rape, Islam, and Law in India", Islamic Studies, Vol. 45, No. 3, pp. 389-412, Autumn 2006.

[29] P. David, "CLIO and the Economics of QWERTY", American Economic Review, Vol. 75, pp. 332-337, 1985. 